\title{
LIX. A Letter to the farmers and graziers of Great Britain; to explain the advantage of using salt in the various branches of agriculture and in feeding all kinds of farming stock
}

\author{
Samuel Parkes F.L.S. M.R.I. F.S.A.E.
}

To cite this article: Samuel Parkes F.L.S. M.R.I. F.S.A.E. (1819) LIX. A Letter to the farmers and graziers of Great Britain; to explain the advantage of using salt in the various branches of agriculture and in feeding all kinds of farming stock , Philosophical Magazine Series 1, 53:253, 343-357, DOI: $10.1080 / 14786441908652153$

To link to this article: http://dx.doi.org/10.1080/14786441908652153

曲 Published online: 23 Jul 2009.

Submit your article to this journal ๘

Џ Article views: 2

Q View related articles $\square$ 
at the top of it, was hauled on shore with a man in it, and then back again, with wonderful facility. Three persons at a time might be forwarded to the shore in this seat with the greatest safety; and after the crew had been secured, property might be taken care of. The persons present expressed their admiration of the principle of the invention; and some able sea-faring men amongst the company were pleased with the cork jacket, and greatly delighted with the new roller, which prevents the friction or entangling of the rope.

"T The experiment would have been complete, had the rope that was conveyed across the Serpentine River been made more taught, and if the rocket which carried it across, and was fired from a musket, had more force or strength. These circumstances might not occur again, and had nothing to do with the invention, which is perfectly simple, and calculated to answer every purpose intended. It has this peculiar advantage, that the line can be thrown from the ship on shore, and the whole apparatus being confined in a small compass, can be ready in every vessel for immediate use.-(Aug. 7th.)"

In this enlightened age, it cannot be too much to hope that every person who has any power will use it in promoting the adoption of this apparatus so much approved;-In the name of humanity $I$ claim it, and am, \&c.

Helston, March 18, 1819.

H. Trengrouse.

LIX. A Letter to the Farmers and Graziers of Great Britain; to explain the Advantages of using Salt in the various Branches of Agriculture and in Feeding all Kinds of Farming Stock. By SAMUel PARKes, F.L.S.M.R.I. F.S.A.E. Efc.

[The author has annexed to his Letter a copious Appendix, to which he makes very frequent reference.- Such of our readers as may be desirous of examining the valuable documents in which it abounds, we must for obvious reasons refer to the Appendix itself.]

Tondon, Feb. 15, 1819. Gentlemen, $I_{N}$ consequence of a late enactinent of the legislature of Great Britain in your favour, and of the share which I took in the preliminary measures for obtaining that enactment, I think it incumbent on me to invite your attention to the subject, by addressing to you, in this public manner, the following observations.

The facts which I shall lay before you are of that importance to your own interests, and the promulgation of them is so likely to promote the welfare of the whole country, that I should consider myself culpable if I omitted to give them the greatest possi- 
ble publicity, or if I neglected to use my best endeavours to place them in that clear point of view which should enable you fully to understand and appreciate them.

The expediency of manuring arable and pasture lands with salt, and of administering the same active and wholesome substance to your horses, sheep, and cattle, as a condiment for their food, and as an efficacious means of preserving them in health and vigour, will form the principal objects which I am anxious to point out for your consideration and future practice.

After a candid and unprejudiced perusal of this letter, you will, I trust, carefully examine the body of evidence which will be adduced in the Appendix, and then make such experiments upon your own estates, and with your own cattle, as are most likely to determine and convince you how far such a course of proceeding may be applicable in your own management.

The ever-memorable Sully, who was one of the greatest men France ever produced, used to say that it ought to be the first maxim of a good government to advance agriculture before manufactures, and to give to the latter only a secondary rank in the state-whereas, Colbert, who was also a great minister, assigned to manufactures the first place in the oeconomical order of his administration, and gave the utmost encouragement to the arts, from a persuasion that their prosperity would furnish the only means of working up the raw materials which his country produced. It is probable, however, that this eminent statesman would not have protected the arts at the expense of agriculture, if he had considered that the principal utility of manufactures in any country arises from the price which they afford to, and the market which they procure for, the products of the soil.

T'he immortal Sully, in vindication of the opinion which I have just quoted, used to say that he had ever preferred the products of the soil, which could not easily be ravished from him, to those foreign conquests which occupy the attention of most governments, but which always excite resentment and jealousy. "A large, and an increasing produce of the land," said he, "ensures the liberty of the people, while it places foreigners in a sort of dependence; whereas the want of corn, the first uecessary of life, gives a dependence upon foreigners, who can either furnish the commodity, or refuse it. The produce of the land," continues he, "cannot be consumed by strangers but to the profit of the inhabitants, that is, by a traffic more advantageous than the possession of the corn itself - whereas the arts and manufactures may possibly be carried off by the artifices of rivals, and pass away, together with the artists themselves, into all the countries of the world."

If these latter sentiments are founded in truth and justice, and 
$I$ believe they are, then every improvement in the agriculture or rural ceconomy of these kingdoms may be considered to be an important national acquisition, and I shall be excused in not offering any apology for endeavouring to call your attention to a practice which is little known in our comtry, but which in some foreign states has invariably been attended with decided advantages as well as profit.

The value of common salt for agricultural purposes has been long known in Germany, in Poland, in Holland, in Flanders, and in all the provinces of the United States of America ; it is therefore much to be lamented that the existing duties should so long have deprived the people of this country of the various benefits which they might have derived from this valuable native production*. The mineral substance of which we are speaking is found in this island in the greatest abundance; yet, by a mistaken policy, we have hitherto given it to strangers, and have allowed many thousands of acres of our own lands, which, by the free use of salt, might have been rendered highly fertile and profitable, to remain nearly sterile, or at least in a state in which they will barely pay for the expense of their cultivation.

However, since the government has so far relaxed as to remit a great part of the duty on such rock-salt as shall forthwith be consumed in agriculture, or in feeding cattle, and as so much depends upon the manner in which this valuable boon is received by the country, it is desirable that the greatest extent of publicity should be given to the act of parliament; and that no agriculturist, not even the most humble gardener, should remain ignorant of the terms and conditions upon which he may now obtain so rich and useful a commodity as rock-salt.

Penetrated with the importance of the subject, and contemplating the variety of advantages which the landed interest must derive from the accomplishment of the measure, the act had no sooner passed than I determined to lay all the particulars before the public, in the hope that these concessions of the legislature, together with the evidence which I should be enabled to offer in proof of the advantages to be derived from the use of salt, would be amply sufficient to induce a large majority of the farmers of Great Britain to acquire such a knowledge of the new regulations as would enable them, without delay, to avail themselves of all the benefits which the government has thus offered for their acceptance.

Having no private ends to answer, and expecting to derive no personal advantage whatever from the general adoption of this

* The value of common salt as a manure was known some hundred years ago by certain individuals in this country, but the high duties and other impediments have prevented its use becoming general. 
measure, I shall proceed to give you a simple outline of the general view which I have taken of the subject. It may, however, be necessary to premise, that my opinions thereon have been formed in consequence of a careful investigation of a great number of well-attested experiments, and from the perusal of that body of evidence which was delivered in the year 1817 before the Lords of His Majesty's most Honourable Privy Council, at the Board of Trade ; and again in the spring of the following year, before a select committee of the House of Commons ; which committee was occupied from day to day, from the sixteenth of March to the fifteenth day of May, in questioning the witnesses, and in recording their respective testimonies upon this most important proposition.

From an attentive examination of all these documents, and from a dispassionate consideration of every thing which $I$ have been able to collect upon this great object, I am decidedly of opinion that rock-salt, at the reduced duty of five pounds per ton, is by far the cheapest, the most efficacious, and the most convenient manure for arable and pasture land, that can possibly be obtained.

More than one hundred and fifty years ago, Sir Hugh Platt, an eminent writer of that day, speaks very decidedly of the benefits which might be derived from the practice of sprinkling common salt upon land, and calls it the sweetest, the cheapest, and the most philosophical marle of all others. He relates the case of a man, who, in passing over a creek on the sea-shore, suffered his sack of seed-corn to fall into the water, and that it lay there until it was low tide, when, being unable to buy more seed, he sowed that which had lain in the salt-water; and when the harvest time arrived he reaped a crop far superior to any in the neighbourhood. The writer, however, adds, that it was supposed the corn would not fructify in that manner unless it actually fell into the sea by chance; and therefore, neither this man nor any of his neighbours ever ventured to make any further use of salt-water.

The same curious author tells us also of " a man who sowed a bushel of salt, long since, upon a small plot of barren ground on Clapham Common, and that to that day (the time when he was writing) it remained more fresh and green than any of the ground round about it."

The eminent Dr. Brownrigg, who wrote in the year 1748, in speaking of common salt, says " it is dispersed over all nature ; it is treasured up in the bowels of the earth; it impregnates the ocean; it descends in rains; it fertilizes the soil; it arises in vegetables; and from them is conveyed into animals; so that it may well be esteemed the universal condiment of nature; 
friendly and beneficent to all creatures endowed with life, whether it be vegetative or animal."

In some parts of Great Britain, particularly in the neighbourhood of the salt works, the value of common salt, as a manure, is well known and acknowledged; and it has lately been given in evidence before the select coinmittee of the House of Commons, by a gentleman of the highest credit, that the farmers in Cornwall are so convinced of the value of salt as a manure*, that whenever the waste salt that has been employed in curing fish is on sale, there is a violent contention among the occupiers of the land, who shall obtain the largest share. The same gentleman informed the committee, that where wheat or barley has followed turnips, on land which had been salted, the ensuing crop has in-. variably escaped the mildew, although that disease had affected all the corn upon the lands immediately adjoining, on which salt had not been used.

The efficacy of salt in destroying noxious weeds, grubs, worms, flies, and insects, is well known in many districts, and those who are incredulous may very easily satisfy themselves by direct experiment. For instance, if a lew common earth worms be taken out of the ground, and sprinkled with a little salt, they will be seen to writhe about for a few minutes, and then expire. Thus salt does, as it were, perform two operations at once; for, by destroying the worms and the weeds, while the land lies fallow, it prepares the ground most effectually for the reception of the corn or the plants, before it can possibly take any effect upon the crop itself. And besides this peculiar advantage, the extreme luxuriance and verdure which common salt gives to grass lands, when properly applied, would be so satisfactory to such farmers who would make use of it, and so convincing to all the neighbouring agriculturists of every description, that if only one or two gentlemen in each district were to employ it in a few instances, I am certain this mode of top-dressing $\uparrow$ would very soon engage the attention of every person in the empire, who had even but a garden to manage and cultivate.

From

* There is also a practice in Cornwall of manuring the lands with seasand for the sake of the salt that it contains; and so very efficacious is this found to be, that a writer, ninety years ago, computed the money laid out in that and the adjoining county for sea-sand to amount to thirty-two thousand pounds per annum; and so much has this practice increased of late years, that Dr. Paris considers " the expense of land-carriage for sand used as a manure in Corawall alone as now amounting at least to thirty thousand pounds annually."

$+I$ think it necessary to remark, that where salt is used as a top-dressing for grass land, the quantity employed ought to be much less than is commonly used for ground that is to be afterwards ploughed for a crop of grain. Six bushels, or three hundred and thirty-six pounds of rock-salt, ground 
From the evidence which has already been collected upon this subject, it is obvious that a great portion of the land in this kingdom might, by the proper use of salt, be made to produce nearly double the amount of the present crops of grass as well as corn. How greatly this would serve the manufacturing, and indeed all other interests of the country, I need not attempt to explain to you. Moreover, by foreing the land with a sufficient portion of salt, our crops would be brought to maturity much sooner than they now are*; a matter of considerable importance in the northern parts of this island, where much of the corn is frequently spoiled by the autumnal rains before it can be sufficiently dried by the sun and wind to stack with safety. And in the hav harvest, should the farmer be induced, from the uncertainty of the weather, to carry his hay too soon, a small quantity of salt sprinkled upon each layer of the rick will prevent the hay from becoming mowburned, as it is called; and when hay which has been thus treated is presented to horses and cattle, it will be preferred by them to that which has been put together in a more favourable season, and not treated with salt.

The cleanliness of rock-salt as a manure is likewise another considerable advantage. In many cases this circumstance will be found to be very important, particularly in the grazing districts. It has repeatedly been observed, that if land be manured with dung after the hay has been carried off, the neat cattle will refuse to eat the eddish which grows upon such land. On the contrary, if a field be dressed with about two busliels of fine salt instead of dung, soon after the hay is cut, this inconvenience and loss will be avoided, and a large crop of aftergrass will be obtained, possessing such peculiar sweetness, that all kinds of cattle, as well as horses, will eat it with the utnost avidity.

The farmers, in some districts, are accustomed to steep their seed-corn in lime-water, and doubtless the practice is often useful; but I am decidedly of opinion that a strong briue, made by the solution of rock-salt in water, will be infinitely more efficacious. Crops of wheat are often reduced one-haif in value by a disease to which this kind of grain is very liable, called the

very fine, and regularly sown upon the grass, would be a proper quantity for an acre of pasture-land: whereas sixteen or twenty bushels may be used upon fallows for cleaning the ground preparatory to the putting in the grain. For meadow-land, two or three bushels of crushed rock-salt may be carefully sown upon each acre, immediately after the hay is got in, with great advantage, especially in hot and dry summers.

* The late Dr. Darwin, in treating on salt as a manure, remarks, ".that as it is a stimulus which excites the vegetable absorbent vessels into greater action than usual, it may, in a certain quantity, increase their growth, by enabling them to take up more nourishment in a given time, and perform their circulations and secretions with greater energy." 
smut or rusl*; but when the seed has been properly prepared with salt, this misfortune can never happen. It has also been proved by some public-spirited individuals, who have made the necessary experiments, that the scab is never found upon potatoes which have grown upon land that has had a proper dressing of common salt.

In mary parts of Flanders, but more particularly at Lisle, it is the practice to preserve the urine of those cattle that eat common salt with their food. This is preserved in appropriate reservoirs; and when the farmers apply it to a certain description of land, which experience has taught them to select, the effect, even without any other manure, is not only advantageous, but it is truly astonishing.

Enough, I presume, has now been offered to induce you to expect a satisfactory result from the application of salt to your fields and meadows; I shall, therefore, at present content myself with informing you, that in the Appendix you will find a list of the names of the gentlemen who have borne testimony to the efficacy of salt as a manure, and likewise the evidence of a gentleman who has used common salt upon his own farm for many years, and has witnessed the use of brine upon the lands in his neighbourhood for forty years, with the greatest advantage; and who came from a distant county on purpose to attend the select committee of the House of Commons, to report to thern the substance of his experience for that very long period. You will also find there the proposals of the Board of Agriculture in London, and of the Highland Society of Scotland, both of which institutions are fully aware of the value of rock-salt in the cultivation of land ; for they have offered rewards to such persons as shall give them an account of the best experiments with this valuable mireral substance, in the different branches of farming, and general agriculture.

We proceed now to the second part of our subject, which relates to the application of salt in feeding sheep and horses, and for assisting in fattening live stock. Here, however, I shall merely enumerate the several advantages which appear to have resulted from the practice, and shall then place my chief reliance on the effect which may be produced by your perusal of the several documents which are contained in the Appendix.

To ascertain the exact quantity of salt which may be necessary for the different kinds of land, and to appreciate the bene-

* I am desirous of recommending to my readers' perusal a very valuable paper, which has lately been distributed gratis by the Board of Agriculture, written by the Right Honourable Sir John Sinclair, bart. "On the means of preventing the rist in wheat by the use of salt," an object well entitled to be ascertained by decisive experiments. 
fits which result from its employment in all the various modes of culture that are adopted in this country, will require several long series of experiments, especially as some of the evidence given before the committee of the House of Commons was unsatisfactory and contradictory; but the advantages which have arisen from giving salt to sheep and cattle are so determinate and selfevident, that there appears to me to be nothing to prevent every farmer from immediately adopting the practice.

The most undeniable evidence has been afforded, that common salt uniformly promotes digestion in horses and cattle, and that this occasions them to make a rapid progress in fattening. It has also been found, that in feeding with chaff or cut straw, a larger quantity of this cheap and ordinary food can be given when sprinkled with salt than can be administered in any other way; and that as the filling the stomachs of cattle while fattening is a circumstance of the greatest importance, a very large portion of chaff, if seasoned with salt, may be given with the utmost advantage to the growth and health of the animals. Thus, every experimental grazier knows that an abundance of very ordinary food, if eaten with relish, will fatten cattle much sooner when given with a small allowance of substuntial provender, than better food alone in a moderate quantity. There is, indeed, hardly any food that can be offered to cattle, which, if mixed with salt, will not be eaten with eagerness. Hence, nothing can be of more importance to a practical grazier than to know how to obtain this valuable saline mineral substance, at a cheap rate, and with little difficulty.

It was given in evidence last year, before the select committee of the House of Commons, that in feeding cattle, fourteen pounds of chaff, such as is produced in winnowing corn, and which of itself is of little or no value, will, when properly moistened and heated by steam, and mixed with two ounces of salt, save fortytwo pounds of turnips. Surely this is a most important circumstance in the ceconomy of a farm. Is it possible that this fact should pass unnoticed by any agriculturist?

A friend of mine, in the year 1812 , travelled through the United States of America, from the state of Massachuset to the River Mississippi. He observed that it was usual, throughout that extensive district, to put salt within all the stacks of hay, and likewise to sprinkle it among the hay, in the proportion of about fourteen pounds of salt to one ton of hay. He says it was also a common practice in that country to give salt to sheep and cattle, and that he has frequently seen cattle follow a boy a mile. or more, who held a portion of salt in his hand, tempting the animals by showing it to them. The same individual assures me also, that since his return to England he has adopted the 
same practice, mixing salt with his own stacks of hay, and with the mashes to his horses, and constantly with the same benefit.

That horses, sheep, and cattle, would derive benefit from salt, might, indeed, be imagined from observing the great desire they discover for it, and which manifests itself in every country where this mineral substance lies within their reach. This is certainly the case, and in the Appendix many undeniable examples will be given to support the opinion. Several most curious facts, that were stated by a very respectable member of the House of Commons, to prove the salubrious effects of salt upon these animals, may also be seen in the Appendix.

It camnot then be doubted that salt, when judiciously administered to live stock, assists their digestion, preserves them from disease, and improves their condition; and from the evidence to be hereafter adduced, it will appear that the milk and butter produced from those cows which have salt given to them is more abundant, and never acquires that turnip-flavour which is generally so predominant in the milk and butter from those cows which are kept upon turnips without salt. It has likewise been proved, that common salt is a certain cure for the botts in horses, and is a specific against the rot in sheep; and that the wool is materially improved of such sheep as are fed with salt.

It is impossible, I conceive, to read the great body of evidence which was delivered to the Honourable the Board of Trade, and to the committee of the House of Commons, without being convinced that the benefits resulting to the grazier and agriculturist, from the emplovment of salt, must be great and important; especially the evidence of John Christian Curwen, esq. the representative in parliament for the city of Carlisle, who is himself a large farmer and grazier, and who stated to the committee, that upon a farm of one thousand pounds a-year, he could not estimate the annual advantages, that might fairly be expected from the free use of salt, at less than three hundred pounds.

If the benefits and profits arising from the unrestrained use of salt in agriculture be so various and considerable, how comes it to pass, it may ke asked, that its employment has not been universal throughout Great Britain? Various reasons may be assigned for this; amongst others we may state the unwillingness which farmers in general evince, especially the lower class, to walk out of the old beaten path of their forefathers; the want of directions how to make use of salt for the purposes under consideration; the enormous duty upon the article itself; and, perhaps, above all others, next to the price, the many vexatious regulations to be observed before a remission of any part of the duty could be obtained.

Let us take one case as an instance of these troublesome obstructions. 
structions. By an act of parliament passed in the 57 th year of George the Third, it was enacted that the farmer might receive salt for the purpose of mixing with the food of sheep or cattle, at the reduced duty of five shillings per bushel, or ten shillings per cwt., such salt to be employed only and for no other purpose than feeding shcep or cattle; but before auy such salt could be obtained, it was necessary to give a bond, with sufficient sureties, to the satisfaction of the Commissioners of His Majesty's Excise, in the penalty of six times the full duty upon such salt ; and no further quantity of salt could be obtained, however much the cattle, after being long accustomed to it, might require its use, until the bond given on the delivery of every prior quantity should be discharged.

It was atso enacted that before such bond could be discharged, a rertificate must be given, declaring the whole of such rock-salt to have been used and consumed in mixing with the food of sheep or cattle, and for no other purpose whatever; and that no such certificate should discharge any such bond, unless the collector of excise should, upon inquiry, be satisfied of the truth thereof, and should underwrite the same upon the said certificate. The act declared also, that if such certificate should not be signed and delivered to such collector before the expiration of thirteen months from the time of the bond being given, or should in any respect be false, or any of the salt should be consumed in any other manuer than in feeding sheep or cattle, the penalty of the bond should be forfeited.

Under such penalties and restrictions, is it at all surprising that salt has not been more generally employed for the purposes above enumerated; especially when it is recollected that, even under all these disadvantages, the farmer could not use a single bushel of salt for curing his hay, for steeping his seed-wheat, or for manuring his land, until he had paid the enormous duty of thirty pounds per ton, which of itself amounted to a prohibition?

I have, however, great pleasure in being able to congratulate you that an act passed both houses of parliament on the fifth of June last, to repeal the most vexatious of these restrictions, and to impose a low duty upon such rock-salt as should be hereafter delivered for any purpose of agriculture, as well as for feeding sheep or eattle.

Under this act of parliament, salt may now be had at the reduced duty of two shillings and sixpence per bushel, or five shillings per cwt.* for any of the following purposes, viz. for mixing with

* Rock-salt is not worth more than eight or ten shillings per ton at the pits of Northwich, and it may be put on board a vessel on the canal for about five shillings per ton more. Persons may be supplied with any quantity of salt on the best terms, and agreeably to the regulations of the late act of 
with the food of sheep or cattle; for steeping seed-corn; for preserving hay, or for manuring land; and no bond is required to be given, nor any sureties as heretofore, for the faithful employment of the salt so obtained. And although the farmer must give a certificate that he has consumed the salt in the way the act directs, it is not necessary that time should be lost, as heretofore, while the collector makes inquiries to satisfy himself of the truth of the allegations in the certificate, but he is bound to accept the same when presented, and the farmer is entitled to receive a further supply of salt immediately.

By this important act of parliament, the farmer is also allowed to remove any part of such salt to another farm, or to sell it to a neighbouring farmer for the purposes aforesaid; and notwithstanding the penalty on a fraudulent misapplication of the salt is fixed by this act at forty shillings the bushel, or at one hundred pounds, according to the determination of the person who shall sue for the same, still the act contains a proviso, that the penalty may be mitigated by a justice of the peace to one-fourth part thereof.

Such are the alterations which have been made in the laws respecting the use of rock-salt in agriculture; and it does appear to me that every farmer who has it in his power to purchase salt should immediately procure a quantity, and make such experiments upon his land and with his live stock as shall appear to him to be most likely to increase the quantity and value of his produce. I am extremely anxious that a great number of agriculturists should immediately enter upon these experiments, because, in my estimation, this concession of the legislature is the greatest boon that the government has ever offered to the acceptance of the landed interest of this country; and that if the occupiers of the land, after the late extraordinary exertions of the select committee of the house of commons for their benefit, should discover an indifference or disinclination to accept of the proffered gift, those interested persons who are enemies to the total repeal of the laws relating to salt will avail themselves of this circumstance as an argument against the advocates for the repeal ; and the whole of the late salt laws will soon be re-enacted in all their original force and severity. Whereas, if experiments were very generally instituted throughout the country, I doubt not but the farmers would soon become so fully convinced of the value of salt for the various purposes of husbandry, that a general application would ere long be made to parliament for a total repeal of

parliament, by applying to Mr. William Horne, a respectable and publicspirited merchant in Liverpool, who has lately been elected an honorary member of the Board of Agriculture in London, for his zeal in promoting agricultural experiments with rock-salt.

Vol. 53. No. 253. May 1819. 
all the laws relating to salt; and such a petition as this would be irresistible. The agriculturist and manufacturer would then be empowered to dig rock-salt with as much freedom as they can now dig sand, or raise coal; ; and the various national betiefits which would result therefrom would be more numerous and important than could easily be enumerated.

Having addressed you at much greater length than I at first intended, all that remains for me now is, that I should give a few necessary cautions and directions to such of my readers as may determine to adopt the practice which bas been recommended in the foregoing pages.

In the first place, I am desirous of remarking that no land can be said to be fruitful which is entirely exhausted of carbonaceous matter; therefore, if it were possible for an estate to be so worn out by successive crops that little or no carbon remained in the soil, it is not likely that salt alone would restore it to its original fertility. I consider also that the land which contains most carbon will derive most benefit from the application of salt. But the safest way for a farmer to proceed is to use his salt sparingly at first, and in all cases to leave a small portion of the same land without salt, so that the real effects produced by the salt may be, by comparison, in every instance, self-evident and palpable.

A farmer who does not wish his land to lie fallow, ought, un. doubtedly, to use too little rather than too much salt; because a very abundant dressing of this saline mineral substance might render the land, for one year at least, absolutely barren. We read in Scripture of the "Valley of Salt," where David sinote the Syrians, which in all probability was an extent of low land that had been rendered barren by an influx of salt water. In one of the very early numbers of the Philosophical Transactions is an account of a valley of the same kind near Aleppo; and the late Dr. Browning relates that there is a vast desert on the frontiers of Russia, towards Crim Tartary, which, in consequence of a superabundance of salt, has become so absolutely sterile, that for the space of many miles neither tree nor herb grows upon it.

This reminds me of a circumstance of primary importance to all those who obtain salt under the regulations of the late act of parliament. This act enjoins that the salt shall be delivered in lumps of twenty pounds each or upwards; consequently the whole of such salt must be broken before it can be used with any advantage; for wherever salt is accumulated upon land, it must inevitably destroy all vegetation that lies beneath it. Now it has occurred to ine that there is a possibility, from the carelessness of a labourer, of its being sometimes spread upon the land without being properly broken; and I am decidedly of opinion, that wherever a lump of rock-salt falls, whether upon arable or pas- 
ture land, it must do mischief. My advice therefore is, that the proprietor of a farm, when he receives a parcel of rock-salt from Northwich, should make a point of having the whole of it ground, or reduced to a powder nearly as fine as common table salt, and passed through a sieve of the requisite fineness, before he allows any of it to be laid upon the ground. Rock-salt is not a hard substance: it may easily be crushed and divided as much as is necessary for any of these purposes.

As to the quantity of salt which it will be advisable to use for the respective crops, and upon the different kinds of land, this will be best learnt by a perusal of the several testimonials and other documents which will be found in the Appendix. But the best way of all others for ascertaining this point would be for every agriculturist to depend upon the results of his own experiments. To this end, I would advise him to institute a set of experiments upon every distinct species of grain which he is in the practice of cultivating, as well as upon his pasture land *, and to keep a register of every minute circumstance attending each of these trials.

A large kitchen-garden, wherever there is one attached to a farm-house, would in some cases be the most appropriate spot for such experiments; as this would be more under the immediate eye of the proprietor, and the experiments being upon a small scale, would be attended with little or no expense. The circumstance of an agriculturist being now empowered to divide the salt which he shill obtain by permit, among as many of the neighbouring farmers as he may think fit, is extremely favourable to such circumscribed experiments, and will be very gratifying to those who may wish to satisfy themselves of the value of common salt, and yet would not like to incur the risk of buying a large parcel solely for their own use. And as the late act allows the use of salt in agriculture, as well as for feeding all kinds of cattle, this affords a large scope for its consumption.

From the trials which have already been made in feeding the live stock upon a farm, it appears that the following quantities may at all times be administered with perfect safety.

To neat cattle four ounces of salt per day, mixed up with steamer chaff or other moistened food; one half to be given in the morning, and the other half in the latter part of the day.

To horses four ounces per day, as aforesaid.

* The right honourable Sir John Sinclair, baronet, lately published a series of sixteen distinct experiments, which he is desirous of having tried by farmers, as best calculated to ascertain the advantages of using salt in agriculture; and he distributed the paper gratis. This valuable sheet, which may be obtained at the Board of Agriculture, is well deserving the attention of all practical men. 
'To young heifers two ounces per day, at twice, as aforesaid.

To calves one ounce per day, divided into two portions.

To sheep two ounces per head per week. The salt to be spread very thin upon slates or tiles in the field where the sheep are fed.

Few farmers or graziers, I flatter myself, will read the foregoing pages, and the Appendix, without feeling some desire to improve their own estates, and increase the value of their live stock by the use of salt; but if there are any who are incapable of feeling a desire for improvement, I trust there are, on the other hand, many country gentlemen and enlightened agriculturists, who rejoice in every opportunity of contributing towards the national improvement of Great Britain, and who will entertain the subject from principles of pure patriotism.

It was the opinion of Aristotle, "that the cultivation of the land is favourable to liberty." And a writer of more modern times remarks, "that well ordered monarchies are most frequently found in highly cultivated and fruitful countries." There was an adage formerly in vogue, that "fields covered with ears of corn are the sources of victories." " The Sardinians," says the President Montesquieu, "w were formerly very rich; and Aristeus, so famed for his love of agriculture, was their lawgiver. But the Carthaginians becoming their masters, destroyed every thing proper for the nourishment of man, and forbade the cultivation of the lands upon pain of death." The state consequently fell into decay, and for ages became the prey of a variety of conquerors. What is most remarkable, however, is, that even to this day the greatest part of the island of Sardinia remains an uncultivated barren waste. To this deplorable state of things the empire of China affords a striking contrast.

" The ancient emperors of China," says Montesquieu, "were not conquerors. The first thing they did to aggrandize themselves gave the highest proof of their wisdom. They raised from beneath the waters (or rather, they recovered from the sea) two of the finest provinces of the empire. These owe their existence to the labour of man; and it is the inexpressible fertility of these two provinces which has given Europe such ideas of the felicity of this vast country." And from the united testimony of travellers, we have reason to believe that every part of this extensive empire is constantly preserved in the highest possible state of cultivation; whereas, in England and Wales alone, there are upwards of seven millions of acres of waste land, which have been for ages, and still continue to be, of little or no benefit to the conmunity.

The greatest obstacle to the cultivation of these lands is the want of manure, there being at present a great insufficiency for 
the lands which are already inclosed. Let the use of rock-salt, however, become general in agriculture, and this defieiency will in a great measure be supplied. Every opulent farmer will then have the means within his reach of putting the whole of his farm into the most desirable state of improvement; so much so, that it would soon be considered disgraceful for any agriculturist to allow a single rood of land belonging to his estate to remain uncultivated. This would prepare the way for the inclosure of those vast tracts of common land which we perceive in every quarter of the united kingdom; and the alteration which this would make in the face of the country, to say nothing of the increase of its inhabitants, may be more easily conceived than described.

Had our ancestors been totally inattentive to the improvement of agriculture, the greatest part of Great Britain would still have been covered with wood; and in like manner, had it not been for the progress of civilization, and the desire of improvement, the finest provinces of France and Germany would still have been overshadowed by the Hercynian forest, which in the time of Julius Cæsar extended from the borders of Alsatia and Switzerland, over the greatest part of Germany, Hungary, and Transylvania, and was said to be sixty day's journey in length and nine in breadth.

"Agriculture," said the late amiable Mr. Hollinshead, " is the most certain source of domestic riches. Where it is neglected, whatever wealth may be imported from abroad, poverty and misery will abound at home. Such is and ever will be the fluctuating state of trade and manufactures, that thousands of people may be in full employment to-day, and in beggary to-morrow. This can never happen to those who cultivate the ground. They can eat the fruits of their labour, and can always by industry obtain, at least, the necessaries of life."

However true these observations nay be, thank God the times in which we live are propitious to every kind of improvement; to the progress of science, as well as to the advancement of the arts; and the spirit of inquiry which is abroad throughout the kingdom, will, I trust, induce many hundred intelligent agriculturists to attend seriously to the important points upon which I have addressed you.

Allow me to add, that I am confident those of you who feel any solicitude upon the suljject, cannot more effectually consult your own best interests, or those of the community at large, than by entering immediately upon such experimental researches as are best suited to your respective situations and convenience, as your success, whatever it may be, will be equally conducive to individual and national prosperity.

I am, Gentlemen, Your most obedient servant, Z 3 SaMuel Parkes. 